\title{
Bilişim Liderliği Ölçeği: Bir Ölçek Geliştirme Çalışması
}

\author{
Informatics Leadership Scale: A Scale Development Study
}

\section{Öz}

Yaşadığımız dünya sürekli değişim ve gelişim süreci olarak tanımlanabilir. Bilişim ise günümüzün önemli kavramlarındandır. Araştırmanın amacı "Biliş̧im Liderliği" ile ilgili algıları ölçen geçerli ve güvenilir bir ölçek oluşturmaktır. Çalışmada, nitel ve nicel araştırma yönteminin bir arada kullanıldığı karma araştırma deseni uygulanmıştır. Ölçek \% 79.315 oranında bir varyansla açılkanmaktadır. Güvenirlik değeri 97 bulunmuştur. Doğrulayıcı faktör analizi sonuçlarının da iyi göstergeleri yansıttığı görülmektedir. Çalışmada geliştirilen bilişim liderliği ölçeği ile mevcut alanyazına ve gelecekte yapılacak çalışmalara önemli katkılar sağlanacağı düşünülmektedir. Sonuçta elde edilen ölçeğin "Bilişim Liderliğı” ile ilgili algıları ölçebilecek başarılı bir ölçek halini aldığı ifade edilebilir.

Anahtar Kelimeler: Bilişim, Liderlik, Bilişim Liderliği, Ölçek Geliştirme

\begin{abstract}
The World that we currently live in can possibly be clarified as the world of rapid changes and development. The purpose of this research is to develop a valid and reliable scale of related perceptions regarding to "Informatics Leadership". A mixed-methods research design with both qualitative and quantitative research methods are conducted. The scale has a variance rate of $79.315 \%$. The reliability value was found as .97 . The results of confirmatory factor analysis reflect good indicators on behalf of the research. It is possible to state that the scale developed in the process of the research is likely to contribute the field of literature and the following research and researchers. The resultant scale can be said to have become a successful scale that can perceive the perceptions of "Informatics Leadership".
\end{abstract}

Keywords: Informatics, Leadership, Informatics Leadership, Scale Development

* İlgili çalışma Doç. Dr. Hasan Arslan’ın danışmanlığında yapılan Mehmet Ulutaş’ın doktora tezinden derlenmiştir. Makalenin ilk hali 10. Ulusal Eğitim Yönetimi Kongresi’nde sunulmuştur.

** Okt. Dr. Çanakkale Onsekiz Mart Üniversitesi, Eğitim Fakültesi, Bilgisayar ve Öğretim Teknolojileri Eğitimi Bölümü, mehmetulutas@comu.edu.tr

*** Doç. Dr. Çanakkale Onsekiz Mart Üniversitesi, Eğitim Fakültesi, Eğitim Bilimleri Bölümü, arslan.phd@gmail.com 


\section{Giriş}

Yaşadığımız dünya sürekli değişim ve gelişim süreci olarak tanımlanabilir. Bilgi çağı olarak adlandırılan bu sürecin esas amacı, insanın daha mutlu, sağlıklı ve refah içinde yaşamasını sağlamaktır. Nitekim bilginin de, insanoğluna bu bağlamda yol gösterici ve işık tutucu misyonu bulunmaktadır. Tüm bireyler ve örgütler bu değişme ayak uydurmak zorunluluğunu hissetmektedir. Konu ile ilgili araştırmaların, her geçen gün yeni birtakım oluşumları insanlıkla paylaştığı düşünüldügünde üniversitelerin bu süreçteki yeri daha önemli görülmektedir.

Günümüzün hızla değişen ve gelişen kimliği çerçevesinde, farklı tanımlamalar ile kişisel roller de beraberinde gelmektedir. Yirmi birinci yüzyıl birçok farklı kavramla açıklanmaya ve tanımlanmaya çalışılmaktadır. Bunlardan birisi de "dijital çağ"dır (Mütercimler, 2006, s. 69). Toplumlarda eğitimin önemi ve yeri nasıl tartışılamazsa günümüz dünyasında sürekli bir gelişme içerisinde olan dijital çağın getirdiklerinin yeri de artık tartışılmaz hale gelmiştir. Özellikle sanayi devrimiyle beraber her geçen gün önemini artırmış, 20 yy’n ortalarından itibaren ise hemen hemen her alanın vazgeçilmez bir olgusu haline gelmiştir. Teknolojinin her alanda önemli bir etkisi olduğu gibi eğitim sektöründe de yeri ve önemi yadsınamayacak derecededir.

Çalışmanın temel kavramı olan, "bilişim liderliğii" hakkında yeterli araştırma ve çalışmaların yok denecek kadar azlığ 1 da dikkat çekicidir. Oysa kavram hayatımıza önemli ölçüde girmiş durumdadır. Bu kavramla ilgili geliştirilen "Bilişim Liderliği Ölçeği” ile literatüre önemli bir katkıda bulunmak araştırmanın temel önemini ortaya koymaktadır.

\section{Bilişsim}

İlk insan toplumlarının en önemli özelliği, temel fizyolojik ihtiyaçlara yönelimdir. Buna yönelik girişilen çabalar sonucunda insan çevresine hâkim olmayı öğrenmiştir. Zamanla toprağın işlenmeye başlamasıyla birlikte çok daha gelişmiş tarım toplumunun hayat koşullarına geçilmiştir. Yönetim anlayışında din, ırk ya da sınıf gibi sosyal kurumlar hâkim olmaya başlamıştır. Sanayileşme ile birlikte makineye yönelim, hızlı kentleşme, zorunlu eğitim ve sanayi toplumu kavramlarını ortaya çıkarmıştır (Fındıkçı, 2012).

Yirminci yüzyıl beraberinde önemli birtakım değerleri beraberinde getirmiştir. Bunlar; kendini gerçekleştirme, sosyal bağlllık ve demokrasidir. Gelişen teknoloji ile birlikte teknik ve araçsal düşünce eğitime hâkim olmuştur. Çok kültürlü gelişimler bireysel değerlere de dikkat çekmektedir. Bireye verilen önemin yanında, uluslararası değerlerin kazandırılması da önemli bir düşüncedir. Ayrıca sosyal, politik, kültürel ve estetik olgular yeni yüzyılın önemli olguları olmuştur (Veugelers \& Vedder, 2003).

Küreselleşme, iletişimdekigelişmelerin doğal sonucudurve kaçınılmaz bir hal almaktadır. Artık fabrikalar sadece yerel pazarlar için üretmemekte, para yerel olma özelliğini kaybederek küresel bir geçerlilik kazanmıştır. Bilgi küreselleşmiş, üretim küreselleşmiş; tüketim küreselleşmiş, sanat küreselleşmiştir. Tüm bu gelişmelerle birlikte toplumların ihtiyaç duydukları insan niteliklerinin küreselleşmemesi mümkün değildir. Artık eğitim sadece ulusal hedefleri değil evrensel değerleri de dikkate almak durumundadır (Şahin, 2001). 
Son yıllarda, sosyo-ekonomik ve teknolojik değişim ve gelişmelere paralel olarak, yönetim paradigmaları da yön değiştirmektedir. Değer temelli üretim, verimlilik, karar verme, bunları uygulama, uygulamaların sorumluluklarını alma, saygı sınırları içinde birbirleri ile anlaşma, rekabet etme, itimat, değerlere dayalı yönetimin anahtar kelimeleridir (Sarıer, 2010). Üniversitelerin bu yapılanmaları kendi bünyesinde bulundurması günümüzde bir zorunluluk haline dönüşmektedir.

Örgütsel etkililik birey ve grup etkinliğini içerse de bunlardan daha ötededir. Bu durum üç boyut açısından etkililiğin dayandığı faktörlere göre değişir. Bu faktörler; örgütün tipi, yaptığı iş ve kullanılan teknolojidir (Karslı, 2004). Teknolojinin önemi, etkili olmak isteyen bir kurumda yadsinamayacaktır.

Bilgisayarlar, etkili iletişim ve işbirliğinde öğretmenlerin kullandıkları bir araç haline gelmiştir. İşbirliği ve değişimi teşvik etmek için bilgisayarların kullanılması bir zorunluluk halini almıştır. Avrupa'da uygulama projeleri bilgisayar ağları ile karakterize edilmiştir. Uygulama projelerinde bilgisayar teknolojilerini kullanma gereksinimleri; işbirliği için öğretmen yetenekleri ve okullarda Bilgi İletişim Teknolojileri (BİT) kullanımı olarak belirtilmiştir. Bilgisayar okur-yazarlığı eğitime daha ciddi ve kalıcı şekilde entegre edilmelidir (Gräsel, 2007).

\section{Liderlik}

Liderlik kavramıyla ilgili birçok araştırma yapılmaktadır. Hem Türkiye'de hem de yabancı ülkelerde hakkında en çok kitap yazılan, seminerler, konferanslar düzenlenen liderlik olgusu üzerinde, klasik tanımlar bir kenara bırakıldığında, halen bir uzlaşmaya varılamadığı görülmektedir. Endüstri çağından bilgi çağına geçişle birlikte liderlik kavramı, iş dünyasında yaşanan devrime uygun olarak 20. yüzyıla göre daha farklı parametrelerle tanımlanmaktadır. Birçok kaynak liderliği, farklı tanım ve rollerle anlatmaya çalışmaktadır (Mütercimler, 2006; Hoy \& Miskel, 2010). Okul yöneticisi için temel sorun, bilgi toplumunun insan tipini yetiştirecek bir okul kültürünü oluşturmasıdır. Kurumda bir bilgi kültürünün oluşturulması gereklidir (Çelik, 2012).

Günümüzde "liderlik" kavramı çok sık duyulmaktadır. Konu ile ilgili özellikle gelişmiş ülkelerde kurslar, ders programları ve hatta bölümlerin açıldığı bilinmektedir. Bu çalışmalar çok eskiye de dayanmaktadır. Son dönemlerde önemli gelişmeleri ülkemizde de görmekteyiz. Sosyal bilimlerde liderlik konusu, farklı açılardan tartışılmakta ve bu tartışmalar oldukça yoğun bir şekilde dikkat çekmektedir.

Liderlik, yönetim alanında araştırma yapan bilim adamlarının çok yoğun olarak çalıştıkları bir konudur. Konu ile ilgili 3000'den fazla ampirik araştırma yapılmıştır (Çelik, 2012). Kavram yeni bir kavram olarak karşımıza çıkmaktadır, 1800’lü yıllara kadar İngilizcede “Liderlik” sözcügü yoktu. Toplumbilimcilerin liderlik olgusu üzerinde ciddi olarak çalışmaları için yüz yıl daha geçmesi gerekecekti. Ancak son kırk yıl içinde araştırmacılar, çok ciddi ve derin araştırmalar sonucu insanların nasıl lider olduklarını, liderliklerini nasıl koruyabildiklerini ve etkili bir lider olabilmek için nelerin gerektiğini öğrenmeye başlamışlardır. Bu çalışmaların sayısı çok gibi görünse de yeni bir alan olarak "liderlik", ufku açık bir alan olarak tanınmaktadır (Gordon, 1999). 
"Liderlik, iki veya daha fazla kişiyi güç ve etki yoluyla yönlendirmedir" (Çelik, 2012, s. 1). Dünyada liderlik ile ilgili yapılmış tüm çalışmalar 3 kuramda toplanmıştır. Bunlardan ilki Özellik Kuramlarıdır. Bu kuramlar, liderlerin özelliklerinin doğuştan getirildiğini savunmuşlar ve askeri, bürokratik liderleri inceleyerek birtakım yargılarda bulunmuşlardır. İlgili kuramlar on üçüncü yüzyıldan on sekizinci yüzyıla kadar liderliği açıklamaya çalışmıştır. İkincisi ise Davranış Kuramlarıdır. Bu kuramlar, on sekizinci yüzyıldan sonra başlamış ve liderlerin özelliklerinin yanında davranışlarını da içine katmışlardır. Liderliği görev boyutu ve ilişki boyutu olmak üzere iki boyutta toplamışlardır. Bu kuramlarla artık liderlik bilimsel olarak çalışılmış bir alan haline gelmiştir. Üçüncüsü ise, Durumsal Kuramlardır. On dokuzuncu yüzyılın ortalarında başlamış ve liderlik kavramının önceden kestirilemeyeceği görüşünü savunmuştur. Her ortamda geçerli olabilecek en etkili liderlik biçimi yoktur denilmektedir (Aydın, 2010; Çelik, 2012; Hoy ve Miskel, 2010).

İnsanlar, istek ve ihtiyaçlarını karşılamak için bir arada yaşamaktadırlar. Amaçları gerçekleştirmek için örgütlenen insan gruplarının oluşturulması ve harekete geçirilmesi, yönetilme gerekliliğini meydana çıkarmaktadır. Bu nedenle liderlik, yönetimin önemli konusu haline gelmiştir (Bakan ve Doğan, 2013).

Tüm insanlık olarak bilgi çağında yaşadığımız yadsınamaz bir gerçekliktir. Bununla birlikte tüm yaşantı alanlarında yaşanan "değişim” kavramı çağımıza damgasını vuran bir kavram halini almaktadır. Günümüzde değişimin iki önemli boyutu bulunmaktadır. Bunlar; teknolojik boyut ve insanlarla örgütlerin düşünsel, fiziksel değişim süreci olarak karşımıza çıkmaktadır. Değişimin karşısında durmak yerine, onu yaşamın bir parçası olarak görmek gerekmektedir (Ünal, 2012). Söz konusu bu değişim okulda liderlik rolünün artık teknik yönetime odaklanmaktan farklı bir yöne doğru kaymakta olduğunu göstermektedir (Gündüz ve Balyer, 2013).

Yıllar içerisinde hayat şartlarının beraberinde getirdiği yeni şartlar ve değişimler, örgütsel anlamda gerçekleşen gelişimler, çalışanların gittikçe artan beklentileri, yapılan liderlik tanımlarını ve liderlik türlerini yetersiz kılmaktadır (Aykan, 2002). Liderin değişmeyi engelleyen değerlerin yerine, değişmeyi sağlayan değerleri yerleştirirse değişme gerçekleşebilir. Kültürel değişimi sağlayıcı yeni gelenek ve sembollerin gelişmesi ve bunların değişen eğitim dünyasında güncelleştirilmesi, dinamik bir kültürün oluşmasında önemli bir paya sahiptir (Çelik, 2012).

\section{Bilişim Liderliği}

Yöneticilerin, okula dişarıdan gelen ve okul içerisinde üretilen her türlü bilgiyi algılamak, anlamlandırmak, gerektiğinde organize etmek ve ilgili bireylere ulaştırmak için bilgi ve iletişim teknolojileriyle barışık olmaları ve bilgi-iletişim teknolojilerini günlük yaşamlarının vazgeçilmezi haline getirmeleri gerekmektedir. Geleceğin gereksinimlerine uygun beklentilerin çoğalması, özellikle eğitim yönetimi alanında çok boyutlu düşünebilmeyi, yeni anlamlandırmalar yapabilmeyi zorunlu kılacaktır. Özellikle bilişim teknolojilerinin yönetsel etkinliklere gelecekte katkıda bulunması bir beklenti olarak görülebilir (Sincar ve Aslan, 2011). 
Alanın çok yeni olması ve dolayısıyla yeterli miktarda bilinçli uygulamanın da olmaması, liderlerin rehber olarak kullanabilecekleri başarılı modellere ihtiyaç duyduğunu anlatmaktadır. Günümüzdeki bilişim teknolojilerinin hızlı gelişmesi yeni yeterlik alanlarını da doğurmaktadır (Bixler, 2000).

İletişim teknolojilerinin yaygınlaşmasıyla yükseköğretim yaşamı yeni bir boyuta girmiştir. Bilginin yaygınlaşması, kullanımının artması ve bilgiye ulaşmanın, haberleşmenin hızlanması olarak tanımlanabilecek bu yeni durum akademik özgürlük gibi değişimleri beraberinde getirmektedir (Yamaç, 2009). Bu durumun içinde akademik yöneticilerin rolleri de değişmekte ve gelişmektedir.

Örgütlerin sürekli değişen koşullara uyum sağlamaları, etkili kararlar alabilmeleri ve hayatlarını devam ettirmeleri, sahip oldukları kaynakları arttırıp yeteneklerini geliştirebilmeleri için bilgi kaynaklarından yararlanmaları, bilgiyi paylaşabilmeleri gerekmektedir. Bilgi paylaşımı ve sürekli öğrenmeyi sağlamak için ise bilgi yönetimine ihtiyaçları vardır. Bu bağlamda yöneticilere ve özellikle liderlere büyük sorumluluk düşmektedir (Doğan ve Kılıç, 2009). Küreselleşmeyle beraber bilgi ve iletişim teknolojilerinin artan önemi ve artan şekilde kullanılışı, bilginin hızlı yayılması, bilgiyi temel üretim faktörlerinden biri konumuna getirmiştir (Karahan, 2009).

Bilgi ve iletişim teknolojilerinde meydana gelen hızlı değişimler ve küreselleşmenin etkileri sonucunda bilgiyi elde etmek, paylaşmak ve kullanmak örgütler açısından çok önemlidir. Yaşanan değişimlerin liderlerin çalışanlarını etkileme yöntemlerinde farklılaşmaya gitmesine neden olmaktadır. Liderlerin değişen çevre koşullarında güven sağlamaları, çalışanları motive etmeleri, onlarla olan iletişimleri teknolojik gelişimlerden etkilenmiştir. Dolayısıyla liderler geleneksel özelliklerinde farklı özellik, beceri ve davranışlara sahip olmalıdır. Bilişim kavramının boyutları olarak sayılan bilgi ve iletişim kavramlarını açıklamak yararlı olacaktır. Bilginin ne olduğunu anlamak için veri ve enformasyon kavramlarını açıklamak gerekmektedir. İngilizcede üç farklı anlama sahip olan "data, information ve knowledge" kavramları sanki aynı anlamı ifade ediyor gibi "bilgi” kavramının yerine kullanılmaktadır (Bakan ve Doğan, 2013,).

Veri (data), bilgiyi inşa eden temel yapıtaşıdır. "Gerçekler ve ölçümlerden ibarettir" (Farkas, 2003, s.3). Enformasyon (information), verilerin anlam kazanan yapılandırılmıs ve işlenmiş halidir. "Veriler ham gerçekler iken, bu verilerin karar alma sürecine destek olacak şekilde düzenlenmiş halleri enformasyon olarak tanımlanır” (Bakan ve Doğan, 2013, s.150). Bilgi (knowledge) ise, bir fikir veya düşünce oluşturmak için eyleme geçmeye olanak sağlayan enformasyon olarak tanımlanabilir (Farkas, 2003). Genel olarak veri, gerçekleri; enformasyon, örgütlenmiş bir veri dizisini; bilgi ise anlamlı enformasyonu tanımlar. Veri ve enformasyon içinde oldukları örgütlere göre ayrılırken, enformasyon ile bilgi arasındaki fark yorumlamaya göre ayrılmaktadır. Bilgi yönetimi de toplumsallaşma sürecinde, bilginin sonraki kuşaklara aktarılmasında ortaya çıkmıştır (Celep ve Çetin, 2003).

Liderlerin amaçları değişmemiştir ama amaçlarına ulaşmak için kullandıkları yöntemler değişmiştir. Liderler kendilerini izleyen çalışanlarının istek ve beklentilerini karşılamak için artık 
günümüzde ana iletişim araçlarından biri olan bilgisayarları kullanmaya başlamışlardır. Bu yeni durum birçok yeni fırsatları beraberinde getirmiştir (DasGupta, 2011).

Bilişim liderliği, tüm okulun desteğini içeren vizyonun paylaşılması kaynaklıdır (Hately ve Schiller, 2003). Öğrenimde bilişim yöneticinin vizyonunu, başkalarının yeteneklerini geliştirmek ve desteklemek amacıyla değiştirmektedir. Bilişim teknolojilerini kullanan ve öğrenmeye çalışan yöneticiler okul kültürü için bilişimin önemini gösteren birer rol model konumundadır (Gronow, 2007). Bilişim liderliği, iletişimi geliştirme amaçlı, bilginin kullanılmasında birey, grup ve örgütleri etkileme gücüne sahip olmak şeklinde ifade edilebilir.

Yapılan birçok bilimsel araştırma, konu ile ilgili teknoloji liderliğini merkeze almaktadır. Ancak tek başına bu liderlik yaklaşımı, günümüzde gelinen gelişimin sadece bir boyutuna odaklanmaktadır. Araştırmamızda, teknoloji liderliğini de kapsayacak olan "bilişim liderliği” olgusu ortaya atılmaktadır. Bu olgu ayrıca alanla daha uygun görülmektedir. "Teknoloji” konusu daha teknik bir konu olarak algılanmaktadır. Ancak "bilişim” konusu bilgi ve iletişim gibi daha yönetsel kavramlardan oluşmaktadır. Konu ile ilgili ulusal çalışma bulunmamakla birlikte uluslararası alanyazında da yeni yeni farklı kavramlarla işlenmeye başlamıştır. Çalışma kapsamında oluşturulan bilişim liderliği ölçeği ile mevcut alanyazına ve gelecekte yapılacak çalışmalara önemli katkılar sağlanacağı düşünülmektedir.

Bilişim liderliği, günümüzde var olması ve üzerinde düşünülmesi gereken bir kavram olarak ifade edilebilir. Hayatın her alanına girmiş olan bilişim kavramın da liderlik durumlarının tespiti bir gereklilik halini almaktadır. Bilişim liderliği ölçeğinin de bu fikirlerle ortaya atıldığ 1 söylenebilir. Ulusal ve uluslararası çalışmalara bu anlamda yeni bir kavram ile bununla ilgili bir ölçeğin 1 şı tutacağ düşünülmektedir.

\section{Amaç}

Bilişim liderliği ile ilgili yapılan araştırmalar sonucu ulusal bazda bir çalışma olmamakla birlikte, belirleyici bir ölçek de bulunmamaktadır. Bu araştırmanın temel amacı, "Bilişim Liderliğì" ile ilgili algıları ölçen geçerli ve güvenilir bir ölçek oluşturmaktır. Bu amaç dâhilinde yapılan analizlerle başarılı bir ölçme aracı geliştirilmeye çalışılmıştır.

\section{Yöntem}

\section{Araştırmanın Modeli}

İlgili çalışmada nitel ve nicel araştırma yöntemleri bir arada kullanılmıştır. Dolayısıyla araştırma, karma araştırma yöntemi niteliği kazanmaktadır. Karma araştırmalar, nitel ve nicel araştırma yöntemlerinin paradigmalarının ya da yaklaşımlarının karışım özelliklerini taşımaktadır. Bu araştırmalarda, nicel ve nitel yöntemleri ile paradigma karakteristiklerinin yer aldığı görülmektedir. Karma araştırmalarla nicel ve nitel yöntemler birbirlerini tamamlamaktadır. Bu gibi araştırmalarda, araştırmacının hangi paradigmalardan, hangi bileşenleri nerede ve hangi 
sorulara ilişkin kullanacağına yönelik pratik çözümler getirmesi gerekir (Balc1, 2010; Johnson ve Christensen, 2014). Karma yöntem, iki tür araştırma yöntemini birleștirerek araștırmalarda her iki yaklaşımın sınırlılıklarını minimuma indirgemektedir. Araştırmada, keşfedici sıralı karma yöntem kullanılmıştır (Creswell, 2014). Bu çalışma şekliyle ilgili imgesel anlatım Şekil 1'de gösterilmektedir.

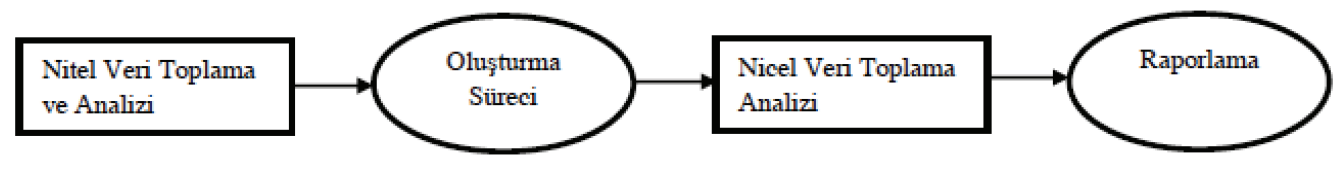

Şekil I. Araştırmanın karma yöntem tasarımı (Kaynak: Creswell, 2014).

Araştırmanın nitel yaklaşımı fenomenolojidir. Fenomenoloji, bir kişinin çeşitli fenomenlerle ilgili deneyimlerini ve bilgilerini betimlemeyi amaçlamaktadır. Bu tür araştırmaların amacı, katılımcıların yaşam ve dünyalarına ilişkin bakış açılarını ve onların yaşam deneyimleriyle yapılandırdıkları kişisel anlamları ortaya çıkarmaktır (Johnson ve Christensen, 2014). Araştırmada, verilerin toplanması ve deneyimlerin betimlenmesi amacıyla nitel araştırma yöntemlerinden "görüşme yöntemi” tercih edilmiştir. Stewart ve Cash (1985) görüşmeyi, “önceden belirlenmiş ve ciddi bir amaç için yapılan, soru sorma ve yanıtlama tarzına dayalı karşılıklı ve etkileşimli bir iletişim süreci” olarak tanımlamışlardır (Aktaran Yıldırım ve Şimşek, 2006, s. 119). Verilerin analizinde, içerik analizi kavramlarından biri olan tümevarımcı analiz tekniği kullanılmıştır. Tümevarımcı süreçte araştırmacı, konunun kapsamlı bir setine sahip oluncaya dek veri tabanı ve temalar arasında ileri-geri çalışmaktadır (Creswell, 2014).

Araştırmanın nicel kısmında "tarama modeli” tercih edilmiştir. Tarama modeli, var olan bir durumu olduğu gibi betimlemeyi amaçlamaktadır (Fraenkel ve Wallen, 2006). Tarama çalışmaları, bir evren içinden seçilen örneklem üzerinde yapılan çalışmalarla evrenin genelindeki eğilim, algı ve tutumların nicel ya da sayısal olarak betimlenmesini, bunun sonucunda birtakım çıkarımlar yapmayı sağlamaktadır (Creswell, 2014).

\section{Çalışma Grubu / Evren ve Örneklem}

“Bilişim Liderliği Ölçeği”nin oluşturulma sürecinde yapılan görüşmelerde nitel boyut devreye girmiştir. Çalışma grubunda Çanakkale Onsekiz Mart Üniversitesi’nde bilişim teknolojileriyle ilgili birimlerde görev yapan sekiz akademik yönetici yer almaktadır. Çalışma grubu ile ilgili genel bilgiler Tablo 1'de sunulmaktadır. Tabloda sunulan akademik yöneticiler için "AY” kısaltması kullanılmıştır. 
Tablo I

Çalışma Grubu İle Illgili Genel Bilgiler

\begin{tabular}{ccc}
\hline Akademik Personelin Kodu & Unvanı & Yöneticilik Yaptı̆̆ Birim \\
\hline AY1 & Prof. Dr. & Bilgisayar Mühendisliği \\
AY2 & Prof. Dr. & BÖTE \\
AY3 & Yard. Doç. Dr. & BÖTE \\
AY4 & Yard. Doç. Dr. & UZEM \\
AY5 & Okutman & UZEM \\
AY6 & Okutman & UZEM \\
AY7 & Okutman & Enformatik \\
AY8 & Uzman & Kütüphane \\
\hline
\end{tabular}

Araştırmada, ölçeğin oluşumu için kullanılan nicel boyutta ise araştırmanın evrenini, Türkiyede yer alan 109 devlet üniversitesinde görev yapan, 18063 profesör, 12323 doçent, 27250 yardımcı doçent, 16361 öğretim görevlisi, 7307 okutman, 3585 uzman ve 42060 araştırma görevlisi olmak üzere toplam 108886 akademisyen oluşturmaktadır (http://www.yok.gov.tr, 01.07.2015). Araştırmanın tüm evrenine ARBİS’ten toplanan e-postalarla ulaşılmaya çalışılmıştır. Dolayısıyla bir örneklem oluşturma çalışması yapılmamıştır. Ancak elde edilen e-posta adresleri üniversite isimleriyle gruplandırılmış ve 2 gruba ayrılmıştır. Birinci grup "Bilişim Liderliği Ölçeği” geliştirme çalışmaları esnasında pilot uygulamada ve açımlayıcı faktör analizi (AFA) esnasında kullanılmıştır. İkinci grup ise doğrulayıcı faktör analizi (DFA) için kullanılmıştır. Üniversiteleri gruplara ayırırken önce tüm üniversitelerin bulunduğu bir tablo hazırlanmıştır. Bu tabloda yer alan üniversiteler kuruluş tarihleriyle bölge bölge yerleştirilmiş ve aralarından uygulamalar için üniversite isimleri belirlenmiştir. Yapılan bu uygulama ile kültürel farklılıkların birbirlerine yakın olması sağlanmaya çalışılmıştır.

\section{Veri Toplama Aracı}

Araştırmanın amacı dahilinde geliştirilen "Bilişim Liderliği Ölçeği”nin oluşturulma sürecinde ilk yapılan çalışmalar nitel veri toplama uygulamalarıdır. $\mathrm{Bu}$ amaçla yarı yapılandırılmış bir görüşme formu hazırlanmış ve akademik yöneticilerin bilişim liderliği ile ilgili görüşleri toplanmaya çalışılmıştır. Hazırlık aşamasında öncelikle toplanmak istenilen veriler doğrultusunda bir form hazırlanmıștır. Oluşturulan formdaki sorular, konu ile ilgili alanyazın taraması ışığında düzenlenmiştir. İlgili form sekiz sorudan oluşmaktadır. Geliştirilen sorular, konu ile ilgili deneyimleri ve çalışmaları olan yedi alan uzmanı ile tartışılmış, madde ekleme, ifadelerin değiştirilmesi, nitel çalışmaya uygunluk gibi birtakım gerekli olan düzeltmelerden sonra son şekillerini almıştır. Görüşme formunun ilk sorusu, değişen koşullar içerisinde üniversitelerdeki yönetici ve liderlere yüklenen sorumluluklarla ilgilidir. İkinci soru ise liderlerin teknolojik gelişmeler sonucunda sahip olması gereken özellik, beceri ve davranışları tespit etmeye yöneliktir. Üçüncü soru “Bilişim Liderliği” kavramına yönelik ifadeleri belirleme amaçlıdır. Dördüncü soru bilişim liderliği ile ilgili yeterliliklerle ilgiliyken, beşinci soru ise 
bilişim liderlerinin çevresindekileri nasıl etkilediğini ortaya çıkarmaya odaklanmıştır. Altıncı soru bilişim liderliğinin alt boyutlarını ortaya çıkarmaya yöneliktir. Yedinci ve sekizinci sorular ise bilgi ve iletişim boyutlarına yönelik uygulamaları tespit etmeye çalışmaktadır. İlgili form, akademik personele onların da izinleri alınarak yüz yüze görüşmeler sonrasında uygulanarak yazılı ve sesli olarak kaydedilmiştir. Formla ilgili geçerlilik ve güvenirliği sağlamak için ilgili alanyazın incelenmiş ve konuyla ilgili kavramsal bir çerçeveden yola çıkarak bir görüşme formu oluşturulup kontrol edilmiştir (Balc1, 2010; Creswell, 2014; Yıldırım, 2006). Yapılan içerik analiziyle temaların birbirleriyle olan ilişkisi kontrol edilerek bütünlük sağlanmaya çalışılmıştır. Ayrıca yedi farklı alan uzmanıyla birlikte görüşme formu incelenmiş ve alınan dönütler doğrultusunda gerekli düzeltmeler yapılmıştır. Bununla birlikte, araştırmanın geçerliği arttırılmak için araştırma süreci detaylı bir şekilde açıklanmaya çalışılmıştır. Bulgular, araştırmanın güvenirliği için yorumlar katılmadan verilmiştir. Araştırma kapsamında kullanılan görüşme formuyla elde edilen veriler, altı alt tema ile ifade edilmiştir. Bu temalar, ilgili alanyazının incelemesinden ve yapılan görüşmelerden sonra şekillenmiştir. Her ana temaya ait olduğu tespit edilen veriler, örneklerle birlikte bulgular başlı̆ğ altında incelenmiştir. Bahsi geçen form Ek A'da sunulmaktadır.

\section{Verilerin Toplanması}

Araştırma için yapılan görüşmeler öncesinde akademisyenlere ulaşılmış ve gerekli izinler sözel olarak alındıktan sonra bir randevu alınmıştır. Görüşme öncesinde ses kaydı için izin alınarak görüşmelerin sesli kayıtları tutulmuştur. Bu ses verileri bilgisayar ortamına aktarılmıştır. Veriler tekrar tekrar okunarak cevaplardaki ortak noktalar aranmış ve bilişim liderliğine ilişkin bir çerçeve çıkarılmaya çalışılmıştır.

Bilişim liderliği ölçeği için yapılan nitel çalışmalardan sonra ölçek oluşturma adımları uygulanmıştır. AFA için "Mailerlite” isimli bir mail gönderme sistemi tarafından akademisyenlere ölçeğin ilk hali ulaştırılmıştır. Ölçek "Surveey" isimli bir anket oluşturma sistemi tarafından yapılandırılmış ve sonrasında belirlenmiş 14266 e-posta adresine ilgili bağlantı sayfası ile gönderilmiştir. Mailerlite sistemi bu gönderilen 14266 mailden tekrar eden, kullanılmayan ya da yanlış yazılan 3467 mail adresini otomatik olarak eleyerek toplam 10799 akademisyenin mail adresine ölçeği göndermiştir. Gönderilen maillerden alınan raporlar doğrultusunda 2484 (\% 24.04) akademisyen tarafından maillerin açıldığı ancak bunlardan sadece 414 (\% 4.01) akademisyen tarafından ölçek linkine tıklandığı görüşmüştür. Bu uygulamadan 11 gün sonra ölçek için aynı gruba bir hatırlatma maili gönderilmiştir. Hatırlatma maili, sistem tarafından 10327 akademisyene gönderilmiştir. Bu gönderim sonrasında 2090 (\% 20.33) akademisyenin maili açtığı ancak bunlardan 240 (\% 2.34) akademisyen tarafından ölçek linkinin tıklandığı raporu alınmıştır. Sonuç olarak 282 akademisyenden alınan veriler doğrultusunda, çalışmanın pilot uygulaması için veri analizine gidilmiştir.

Araştırmanın DFA için de e-postalar aracılığıyla veriler toplanmıştır. İlgili uygulama için yine "Mailerlite" isimli mail gönderme sistemi kullanılmıştır. Çalışmanın veri toplama aracı "Surveey" isimli anket oluşturma sistemi ile oluşturulmuş ve belirlenmiş olan 36336 e-posta adresine 
ilgili bağlantı sayfası gönderilmiştir. Mailerlite sistemi; bu gönderilen 36336 mailden tekrar eden, kullanılmayan ya da yanlış yazılan 9348 mail adresini otomatik olarak eleyerek toplam 26988 akademisyenin mail adresine ölçeği göndermiştir. Gönderilen maillerden alınan raporlar doğrultusunda 7902 (\% 33.4) akademisyen tarafından maillerin açıldığı ancak bunlardan sadece 102 (\% 0.43) akademisyen tarafindan ölçek linkine tıklandığ 1 görülmüştür. Bu uygulamadan 10 gün sonra ölçek için aynı gruba bir hatırlatma maili daha gönderilmiştir. Hatırlatma maili sistem tarafından 22384 akademisyene gönderilmiştir. Bu gönderim sonrasında 9132 (\% 41.11) akademisyenin maili açtığını ancak bunlardan 1463 (\% 6.59) akademisyen tarafından ölçek linkinin tıklandığı raporu alınmıştır. Sonuç olarak 1203 (\% 4.45) akademisyenden veriler toplanmıştır.

\section{Verilerin Analizi}

Ölçek geliştirme sürecinin bir boyutu olarak, yapısal eşitlik modellemesi (YEM) kullanılmıştır. YEM, ile doğrulayıcı faktör analizi de yapılmıştır. YEM’in özünde, sağlam teorik çatının yer aldığı bir modelin sınanması amaçlanır (Şimşek, 2007; Hair, Black, Babin, Anderson ve Tahtam, 2006). Yapı geçerliliğine yönelik AFA ve güvenirlik analizlerinde SPSS 21 Programı kullanılmıştır. DFA için AMOS 20 Programından faydalanılmıştır. Yapısal eşitlik modellemesi ile ilgili yapılan uyum indeksleri için kabul edilen bazı değerler ise aşağıda yer alan Tablo 2'de verilmektedir.

\section{Tablo 2}

Uyum Indeksleri ve Referans Değerler

\begin{tabular}{|c|c|c|c|}
\hline İndeks & Aralık & Referans Değerler & Kaynak \\
\hline$X^{2}$ & $\mathrm{p}>.05$ & - & - \\
\hline$X^{2} / \mathrm{df}$ & $0-\infty$ (Yüksek-Düşük) & $\begin{array}{l}<3 \\
<2 \text { (iyi uyum) } \\
<2,5 \text { (küçük örneklem) } \\
<5 \text { (orta düzey uyum) }\end{array}$ & $\begin{array}{l}\text { Kline (1998), Sümer (2000) } \\
\text { Tabachnick ve Fidel (2007) } \\
\text { Kline (1998), Sümer (2000) }\end{array}$ \\
\hline GFI & 0 - 1 (Düşük-Yüksek) & $\begin{array}{l}>.90 \\
>.90 \text { (iyi uyum) }\end{array}$ & $\begin{array}{l}\text { Kline (1998) } \\
\text { Sümer (2000) }\end{array}$ \\
\hline AGFI & 0 - 1 (Düşük-Yüksek) & $\begin{array}{l}>90 \\
>.95 \text { (mükemmel uyum) }\end{array}$ & $\begin{array}{l}\text { Sümer (2000) } \\
\text { Sümer (2000) }\end{array}$ \\
\hline CFI & 0 - 1 (Düşük-Yüksek) & $\begin{array}{l}>.95(\mathrm{~N}<250) \\
>.95 \\
>.90\end{array}$ & $\begin{array}{l}\text { Hair ve Ark. (2006) } \\
\text { Tabachnick ve Fidel (2007) } \\
\text { Sümer (2000) }\end{array}$ \\
\hline RMSEA & 0 - 0.1 (Yüksek-Düşük) & $\begin{array}{l}<.05 \\
<.06 \text { (iyi uyum) } \\
<.08(\mathrm{~N}<250) \\
<.1(\text { zayif uyum })\end{array}$ & $\begin{array}{l}\text { Sümer (2000) } \\
\text { Tabachnick ve Fidel (2007) } \\
\text { Hair ve Ark. (2006), Sümer } \\
\text { (2000) } \\
\text { Tabachnick ve Fidel (2007) }\end{array}$ \\
\hline
\end{tabular}

Kaynak: Türkmen, 2011, s. 51. 


\section{Bulgular}

Ölçek için yapılandırılmış bir geliştirme süreci yürütülmüştür. Öncelikle Çanakkale Onsekiz Mart Üniversitesi’nde görev yapan akademik yöneticilerin bilişim liderliği kavramı ile ilgili olabilecek görüşleri alınmıştır. İlgili çalışmada Bilgisayar ve Öğretim Teknolojileri Öğretmenliği Bölüm Başkanı ve Başkan Yardımcılarının, Bilgisayar Mühendisliği Bölüm Başkanının, Uzaktan Eğitim Uygulama ve Araştırma Merkezi Müdür ve Müdür Yardımcılarının, Enformatik Bölümü Başkan Yardımcısının ve son olarak da Kütüphane ve Dokümantasyon Daire Başkanının görüşlerine başvurulmuştur. Belirlenen bu grubun bilişim kavramıyla yakından ilgisi oluğu düşünülerek ilgili görüşmeler planlanmıştır. Toplam sekiz akademik yöneticiden alınan bu görüşler doğrultusunda ölçek için uygun olabilecek boyutlar belirlenmiş ve bu boyutlara ilişkin madde havuzunda kullanılabilecek ifadeler alınmıștır. Araştırmacının konu ile ilgili oluşturduğu maddeleri ve alınan görüşler doğrultusunda ortaya çıkan maddelerle birlikte 94 maddelik bir ölçek madde havuzu oluşturulmuştur. Bu madde havuzuna ek olarak incelenen alanyazın yardımıyla oluşturulan maddelerle birlikte toplam 153 maddelik bir madde havuzu meydana getirilmiştir. Oluşturulan madde havuzu 15 alan uzmanına sunularak ilgili değerlendirmelerin yapılması sağlanmıştır. Gelen öneriler doğrultusunda 71 maddelik hâli ortaya çıkmıştır. Ölçekle ilgili geçerlik ve güvenirlik uygulaması ile maddelerin azaltılmasına ilişkin bir ön uygulama yapılmasına karar verilmiştir. Ön uygulama 38 akademisyenle yapılmıştır. Ön uygulamada ayrıca ölçek ile ilgili görüşler, ölçeği uygulayan 12 akademisyenden alınarak maddeler tekrar gözden geçirilmiştir. Sosyal Bilimler İçin İstatistik Programı (Statistical Package for the Social Science [SPSS]) 21 Paket Programıla uygulanan 71 maddelik ölçek ayrıca KolmogorovSmirnov (K-S) testine tabi tutulmuş, .05’in altında olan maddeler ölçekten çıkarılmıştır. Bu görüşler ve uygulanan K-S testi sonucunda 26 , yapılan tekrar tekrar okumalardan sonra da iki madde çıkarılarak 43 maddeye sahip bir ölçek oluşturulmuştur. Ölçeğin 43 maddelik bu hâli, pilot çalışma için önceden belirlenmiş örneklem grubuna e-posta yoluyla gönderilmiştir. Pilot uygulama sonucunda 282 kişiden dönüt alınmıștır. Alınan bu dönütler, SPSS programında güvenirlik ve AFA'ya tabi tutulmuştur. Elde edilen ölçeğin, esas uygulaması sonrasında yapılan doğrulayıcı faktör analizinde ise AMOS 20 programından yararlanılmıştır.

Ön uygulama sonucunda, ölçeğin Cronbach alfa değeri 98 bulunmuştur. Ölçek KaiserMeyer-Olkin (KMO) değeri de .98'dir. Bartlett's değeri ise .000 ile anlamlı çıkmıştır. Ölçeğin ön uygulamasını oluşturan 43 maddenin ayırt edicilik güçlerinin .595 ile .893 arasında olduğu görülmüştür. Bu da ölçeğin iyi geliştirilmiş olduğunu anlatmaktadır. Yapılan faktör analizleri sonucunda 43 maddenin 34'ünün öngörülen boyutlarda net bir şekilde yer aldığ görülmüştür. Faktör analizinde ilgili boyutlarda yer almayan ve boyut ayrımlarında net bir farkı görünmeyen dokuz madde ölçekten çıkarılmıştır. Ölçeğin, özdeğeri 1'den büyük olan ve daha önceden de öngörülmüş 3 ayrı boyuttan oluştuğu analiz sonrası tespit edilmiştir. Ölçeğin “iletişim” boyutu altı madde, "yönlendirme" boyutu 17 madde ve "bilgi" boyutu ise 11 maddeden meydana gelmiştir.

Ölçeğin pilot uygulamasından sonra çıkarılan 9 maddeden sonra tekrar yapılan faktör analizi neticesinde Kaiser-Meyer-Olkin (KMO) değeri de .97 ve Bartlett’s değeri ise .000 çıkmıştır. Analiz esnasında öngörülen boyutlara uymayan bir madde daha analizlerden çıkarılıp tekrar 
çalıştırılmıştır. Bu analizler sonucunda 33 maddelik bir ölçek, yapı geçerliliği ve açımlayıcı faktör sonrasında başarılı bir şekilde elde edilmiştir. Ölçeğin üç boyutunu oluşturan maddelerin eşit şekilde dağılımının yapılması kararlaştırılmış ve AFA sonrasında başarılı bulunan ölçeğin 18 maddelik hâlinin işe koşulmasına karar verilmiştir. Ölçeğin son hâline ilişkin bilgiler Tablo 3'te verilmektedir. İlgili ölçeğin ilk faktörü “yönlendirme”, ikinci faktörü “iletişim” ve üçüncü faktörü ise "bilgi"dir.

Tablo 3

Bilişim Liderliği Ölçeği Döndürülmüş Bileşen Matrisi

\begin{tabular}{|c|c|c|c|}
\hline \multirow{2}{*}{ Maddeler } & \multicolumn{3}{|c|}{ Faktörler } \\
\hline & 1 & 2 & 3 \\
\hline s36 & .851 & & \\
\hline s37 & .844 & & \\
\hline s40 & .825 & & \\
\hline s38 & .824 & & \\
\hline s32 & .791 & & \\
\hline s33 & .758 & & \\
\hline s21 & & .820 & \\
\hline$s 20$ & & .803 & \\
\hline$s 23$ & & .700 & \\
\hline s 25 & & .653 & \\
\hline s24 & & .645 & \\
\hline$s 22$ & & .640 & \\
\hline s4 & & & .734 \\
\hline s2 & & & .722 \\
\hline s1 & & & .695 \\
\hline s6 & & & .655 \\
\hline s7 & & & .650 \\
\hline s5 & & & .603 \\
\hline$\%$ varyans & 33.023 & 23.690 & 22.602 \\
\hline Toplam \% varyans & 79.315 & & \\
\hline Güvenirlik & .970 & .944 & .907 \\
\hline Güvenirlik genel & .970 & & \\
\hline KMO & .964 & & \\
\hline BARTLETT & $5557.784 \quad(\mathrm{p}=.000)$ & & \\
\hline
\end{tabular}

Tablo 3’te de görüldüğü üzere, ölçekle ilgili değerler başarılıdır. Ölçek \% 79.315 oranında bir varyansla açıklanmaktadır. Güvenirlik değerlerinin iyi olduğu ve genel güvenirliğin .97 olduğu dikkat çekmektedir. Geliştirilen ölçeğin DFA ile ilgili ölçüm modeli Şekil 2'de verilmektedir. 


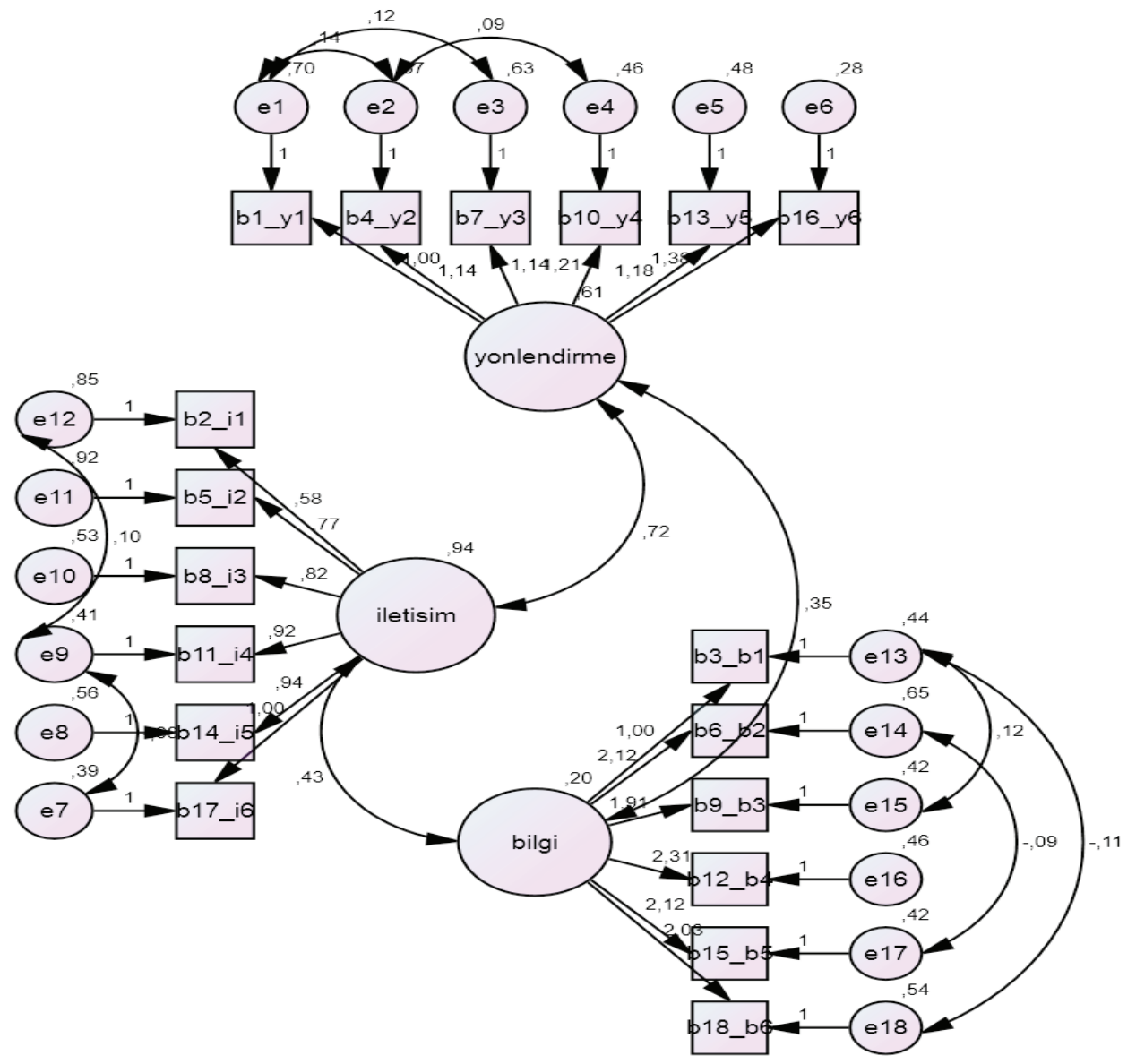

Şekil 2. Bilişim liderliği ölçeği doğrulayıcı faktör analizi ölçüm modeli

Şekil 2'de bilişim liderliği ile onu oluşturan ilgili boyutların ve bunlara ilişkin maddelerin yer aldığı doğrulayıcı faktör analizi doğrultusunda çizilen model gösterilmektedir. İlgili modelde yer alan değerlerin uygun oldukları da ifade edilebilir. Bu modelle ilişkili uyum indeksleri ise Tablo 4 'te verilmektedir.

Tablo 4

Bilişim Liderliği Ölçeği Doğrulayıcı Faktör Analizi İçin Uyum İndeksleri

\begin{tabular}{|c|c|c|c|c|c|c|c|}
\hline$X^{2}$ & Df & P & $X^{2} /$ df & GFI & AGFI & CFI & RMSEA \\
\hline 328.901 & 124 & .000 & 2.652 & .873 & .825 & .941 & .081 \\
\hline
\end{tabular}

Yapılan doğrulayıcı faktör analizi sonrasında çıkan sonuçların da iyi göstergeleri olduğu görülmektedir. Ki-kare/serbestlik derecesi $\left(X^{2} / \mathrm{df}\right)$ değerinin 3'ün altında olması iyi düzey bir 
uyumun sağlandığını, Uyum İyiliği İndeksi (Goodness-of-fit index [GFI]) değerinin .873 olması bir uyumun varlığını, Uyarlanmış Uyum İyiliği İndeksi (Adjusted Goodness-of-fit index [AGFI]) değerinin .825 olması uyum değerine yakın olduğunu, Karşılaştırmalı Uyum İndeksi (Comparative Fit Index [CFI]) değerinin .941 olması da iyi bir uyumun olduğunu ve son olarak Ortalama hata karekök yaklaşımı (Root-meansquare error approximation [RMSEA]) değerinin .081 olması da iyi bir uyumun varlığını göstermektedir.

\section{Sonuç ve Tartışma}

Ölçek hazırlama çalışmalarında yapılan görüşmelerde bilişim liderliğinin, teknolojiyi bilme, kullanma gibi yeterliliklere sahip olması gerektiği ortaya çıkmıştır. Liderlerin teknolojikgelişmelere bağlı olarak kendilerini hazırlamaları ve en azından bu olguyu önemli görmeleri gerekmektedir. Dolayısıyla yöneticilerin teknolojiyi temele alan bir iletişim kurması artık günümüzde önem kazanmaktadır. Bu bağlamda liderlerin yenilikleri kullanma, onların yaygınlaşmasını sağlama ve paylaşımını yapma gibi temel üç beceriye sahip olması önemli bir husustur. Bunları yapabilmesi için ayrıca birtakım bilişim yeterliliklerine de sahip olması gerekmektedir. Türkaslan (2011), bu yeterlilikleri tespit etmek amacıyla "Bilişim Teknolojileri Yeterlilik Standartları" geliştirmiştir. Bu yeterliliklerin temel düzeyde de olsa yöneticilerde bulunması önerilmiştir. Bu safhada yöneticinin kendisini bu konuda hazırlaması gerekmektedir. Onat (2007) da teknolojik gelişmelerin örgüt yapılarında da değişikliğe yol açtığını ifade etmiş ve bilişim teknolojileri uygulamalarının yönetimdeki öneminin altını çizmiştir.

Liderliğin bir etkileme süreci olduğu ortaya konulmuştur. Bilişim lideri bu etkileme gücünü bilişim teknolojilerini kullanarak, bu alandaki becerilerini sergileyerek, kurduğu iletişimlerinde sosyal medya gibi teknolojilerden yararlanarak, çevresindekilere model olarak, gerektiğinde kendini izleyenleri ödüllendirerek, katılımcı bir vizyon belirleyerek ve araştırmacı kişiliğini ortaya koyarak göstermektedir. Richardson ve McLeod (2011) ile Beytekin (2014) ilgili çalışmalarda yöneticiler için teknoloji standartlarını vurgulamışlar ve bu standartların üzerine araştırmalarını yürütmüşlerdir.

Bilişim liderliği kavramının paylaşma ile öne çıktığg söylenebilir. Liderlik, etki ile ortaya çıkan bir güçtür. Çelik (2012), liderliğin etki üzerine meydana geldiğini yaptı̆̆ tanımda ortaya koymuştur. Bilişim lideri de bu etkiyi yaparken bilişim teknolojilerinden yararlanan bir lider konumundadır. Lider, aynı zamanda çevresindekileri bir amaç doğrultusunda yönlendiren kişidir. Araştırmada yönlendirme ayrı bir boyut olarak bilişim liderliğini nitelemektedir. Ayrıca bilişim lideri bilişim teknolojilerini bilen ve onları kullanan bir bireydir. Dolayısıyla böyle bir altyapıya da sahip olmalıdır. Araştırmadaki neredeyse tüm görüşmelerin odak noktası olan yeniliklere açık bir role sahip oluşu ile bilişim liderliği, belki de diğer liderlik türlerinden ayrılmaktadır. Ayrıca bunun devamını getirmesi için bilişim liderinin eğitim faaliyetlerini başlatıcı ve devam ettirici bir role de sahip olması gerekmektedir. Bu ortamları sağlayıp kaynak ulaşımına da olanak sunması da önemli olan bir başka özelliğidir. Lider tüm bu özelliklere tabi ki bilimsel değerleri ön plana alarak sahip olmalıdır. Bilişim lideri, bilginin ve iletişimin gücüyle yönlendirme işini yapan kişidir. Belki 
de tüm liderlerin olması gerektiği gibi ekibi tarafından onaylanan ve sevilen bir bireydir. Vizyon sahibi oluşu, geleceği görmesi ve bunu katılımcı bir ortamda paylaşması da bilişim liderinden beklenen bir davranıştır. Davies (2013) çalışmasında bu sonuçları onaylamaktadır. Bilişim liderliğinin eğitim kurumlarında önemli konu olduğunu, okullardaki bilişim teknolojilerinin önemini, bilişim teknolojileriyle kurumun sahip olduğu bilginin, uygulama faaliyetlerini ve çevresinin etkilediğini vurgulamıştır.

Araştırma çerçevesinde yapılan analizler ve alınan uyum indeksleri, ölçeğin genel olarak iyi bir uyuma sahip olduğunu ortaya koymaktadır. Sonuçta elde edilen ölçeğin "Bilişim Liderliği” ile ilgili algıları ölçebilecek başarılı bir ölçek halini aldığı ifade edilebilir. İlgili ölçek, farklı alanlarda ve farklı katılımcılarla önemli bulgulara erişilebilecek bir veri toplama aracı durumundadır.

Geliştirilen ölçek, madde sayısı ve sahip olduğu istatistiksel değerler ile kullanıma uygun bir haldedir. Bu anlamda literatüre önemli bir katkı sağlayacağı düşünülmektedir. Tabi ki yapılacak çalışmalarda kullanılan farklı örneklemler doğrultusunda geliştirilmesi de gerekecektir. Ancak başlatıcı olması açısından farklı çalışmalarda kullanılmasının önemli olduğu söylenebileceği gibi diğer araştırmacılar tarafından da gelişimine katkı sağlanması da beklenmektedir. 


\section{Kaynaklar}

Aydın, M. (2010). Ĕ̆itim Yönetimi (9. Baskı). Ankara: Hatiboğlu.

Aykan, E. (2002). Girişimcilik ve girişimcilerin liderlik davranışları. (Yayınlanmamış yüksek lisans tezi). Erciyes Üniversitesi, Kayseri.

Bakan, İ. ve Doğan, İ.F. (2013). Liderlik: Güncel konular ve yaklaşımlar. Ankara: Gazi.

Balc1, A. (2010). Sosyal bilimlerde araştırma: yöntem, teknik ve ilkeler (8. Baskı). Ankara: Pegem Akademi.

Beytekin, O. F. (2014). High school administrator's perceptions of their technology leadership. Educational Research and Reviews, 9(14), 441-446.

Bixler, H. C. (2000). Creating a dynamic knowledge management maturity continuum for increased enterprise performance and innovation. (Unpublished doctoral dissertation). The George Washington University, Washington D.C.

Celep, C. ve Çetin, B. (2003). Bilgi yönetimi: Örgütlerde bilgi paylaşım kültürü yaratma. Ankara: Anı.

Creswell, J. W. (2014). Nitel, nicel ve karma yöntem yaklaşımları araştırma deseni (Çev. Ed. S. B. Demir). Ankara: Eğiten Kitap.

Çelik, V. (2012). Eğitimsel Liderlik (6. Baskı). Ankara: Pegem.

DasGupta, P. (2011). Literature review: e - leadership, Emerging Leadership Journeys, 4(1): 1-36).

Davies, P. M. (2013). Student leadership of ICT for learning in a high school (Unpublished doctoral dissertation). The University of Manchester, Manchester.

Doğan, S. ve Kılıç, S. (2009). Bilgi yönetiminde liderliğin rolü üzerine kavramsal bir inceleme, Süleyman Demirel Üniversitesi İktisadi ve İdari Bilimler Fakültesi Dergisi, 14(2): 87-111.

Farkas, F. (2003). The role of leadership in knowledge management and knowledge transfer, Lengyel, I. (Ed). Knowledge Transfer, Small and Medium-Sized Enterprises and Regional Development in Hungary: Jate Press, 1-14.

Findıç̧ı, İ. (2012). İnsan Kaynakları Yönetimi (8. Baskı). İstanbul: Alfa.

Fraenkel, J. R. ve Wallen, N. E. (2006). How to design and evaluate research in education. New York: McGrawHill Education.

Gordon, T. (1999). Etkili Liderlik Eğitimi Katılımcı Yönetimin Temeli. Emel Aksay (Çev.). İstanbul: Sistem.

Gräsel, C. (2007). The Use of Computer Tools in Implementation Projects in Schools. Research in Comparative and International Education, 2 (1).

Gronow, M. (2007). ICT leadership in school education. "Directions for Catholic Education Leadership in the 21st Century" Australian Catholic University Conference.

Gündüz, Y. ve Balyer, A. (2013). Gelecekte Okul Müdürlerinin Gerçekleştirmeleri Gereken Roller. Anadolu Üniversitesi Sosyal Bilimler Dergisi, 13(3), 45-54.

Hair, J. F., Black, W. C., Babin, B. J., Anderson, R. E. ve Tahtam, R. L. (2006). Multivariate data analysis. New Jersey: Pearson Education Ltd.

Hately, N., ve Schiller, J., (2003) What personal ICT skills do school leaders need? The Practicing Administrator, 4, 5 - 7.

Hoy, W. K. ve Miskel, C. G. (2010). Eğitim yönetimi teori, araştırma ve uygulama. (Çev. S. Turan). Ankara: Nobel.

Johnson, B. ve Christensen, L. (2014). Educational research (quantitative, qualitative, and mixed approaches (4th Edition), (Çev. Ed. S. B. Demir). Ankara: Eğiten Kitap.

Karahan, A. (2009). Bilgi liderliğinin verimlilik üzerine etkisi: sağlık sektöründe bir araştırma, Bilgi Dünyası, 10(1): 60-79. 
Karsl1, M.D. (2004). Yönetsel Etkililik (2. Baskı). Ankara: PegemA.

Mütercimler, E. (2006). Geleceği Yönetmek (2. Baskı). İstanbul: Alfa.

Onat, F. (2007). Bilişim teknolojilerinin yaygınlaşması ile değişen örgüt yapılarında halkla ilişkilerin rolü: network örgüt yapılarına yönelik bir çalışma (Yayımlanmamış doktora tezi). Ege Üniversitesi, İzmir.

Richardson, J. W. ve McLeod, S. (2011). Technology leadership in Native American Schools. Journal of Research in Rural Education, 26(7). Retrieved from http://jrre.psu.edu/ articles/26-7.pdf.

Sarıer, Y. (2010). Değerlere Dayalı Okul Yönetimi. Çağdaş Eğitim Dergisi, 35(373), 30-37.

Sincar, M. ve Aslan, B. (2011). İlköğretim Öğretmenlerinin Okul Yöneticilerinin Teknoloji Liderliği Rollerine İlişkin Görüşleri. Gaziantep Üniversitesi Sosyal Bilimler Dergisi, 10(1), 571 - 595.

Şahin, İ. (2001). Küreselleşme Dijital Teknoloji ve Eğitimde Yeni Yaklaşımlar. Uluslararası Eğitim Teknolojileri Sempozyumu, Bildiri Metni, Sakarya.

Şimşek, Ö.F. (2007). Yapısal eşitlik modellemesine giriş. Ankara: Ekinoks.

Türkarslan, U. (2011). İlköğretim okulu yöneticilerinin bilişim teknolojileri alanındaki yeterlik standartlar (Yayımlanmamış doktora tezi). Hacettepe Üniversitesi, Ankara.

Türkmen, M. (2011). Öznel iyioluşun yapısı ve anababa tutumları, özsaygı ve sosyal destekle ilişkisi: Bir model sınaması (Yayımlanmamıs doktora tezi). Ankara Üniversitesi, Ankara.

Ünal, M. (2012). Bilgi çağında Değişim ve Liderlik. Marmara Üniversitesi İ.İ.B.F. Dergisi, 32(1), 297-310.

Veugelers, W., Vedder, P. (2003). Values in Teaching. Teachers and Teaching: theory and practice, 9 (4).

Yamaç, K. (2009). Bilgi Toplumu ve Üniversiteler. Ankara: Eflatun.

Yıldırım, A. ve Şimşek, H. (2006). Sosyal bilimlerde nitel araștırma yöntemleri (6. Baskı). Ankara: Seçkin.

\section{Ek A: Bilişim Liderliği Görüşme Formu}

\section{Görüşülen:}

\section{Görüşmeci:}

\section{Tarih ve Saat (Başlangıç ve Bitiş):}

Sayın Akademisyen,

$\mathrm{Bu}$ görüşme formu, üniversitelerdeki akademik yöneticilerin, bilişim liderliği ile ilgili görüşlerini almak amacıyla hazırlanmıştır. İlgili form ile bilimsel bir çalışmanın nitel boyutuyla ilgili verilerin toplanacağı düşünülmektedir. Elde edilecek bilgiler, bilimsel amaçlar doğrultusunda değerlendirileceği için, kişisel bilgilerinizi ifade etmeniz gerekmemektedir. Araştırmaya katılımda gönüllülük esastır. Kapsam geçerliliğini sağlamak için tüm soruları yanıtlamanız büyük bir önem arz etmektedir.

İlginiz ve yardımlarınızdan dolayı şimdiden teşekkür eder, çalışmalarınızda başarılar dileriz.

Okt. Mehmet Ulutaş (mehmetulutas@comu.edu.tr)

1. Örgütlerde etkili kararlar almak, örgütlerin devamlılığı için sürekli değişen koşullara uyum sağlamak, sahip olunan kaynakları arttırıp yetenekleri geliştirmek için bilgi ve iletişim teknolojilerinden yararlanılması ve kurum içinde paylaşılabilmesi gerekmektedir. Bu bağlamda yöneticilere ve özellikle liderlere büyük sorumluluklar düşmektedir. Karmaşı bir örgüt olan 
üniversitelerde yönetici ve liderlere ne gibi sorumluluklar yüklenebilir? Örneklerle açıklar misinız?

2. Liderler, üyesi olduğu örgütte güven sağlamak, çalışanlarını motive etmek ve onlarla olan iletişimlerinde etkili olmak için teknolojik gelişmelerden yararlanmalıdır. Dolayısıyla liderler geleneksel özelliklerinden farklı birtakım özellik, beceri ve davranışlara sahip olmalıdır.

a. Liderlerin teknolojik gelişimlere paralel olarak sahip olması gereken özellikleri neler olabilir?

b. Liderlerin teknolojik gelişimlere paralel olarak sahip olması gereken becerileri neler olabilir?

c. Liderlerin teknolojik gelişimlere paralel olarak sahip olması gereken davranışları neler olabilir? Örneklerle açıklar mısınız?

3. Yükseköğretimde "Bilişim liderliği” kavramı size ne ifade etmektedir? Açıklar mısınız?

4. Günümüzdeki yükseköğretimde yer alan akademik yöneticilerin sahip olması gereken bilişim liderliği ile ilgili yeterlikleri neler olabilir? Örnek vererek açıklar mısınız?

5. Liderlik en genel anlamda kendini izleyen birey ya da grupları etkileme süreci olarak tanımlanır. Akademik yöneticiler, kendini izleyenleri etkileme sürecinde bilişim liderliğini nasıl kullanabilir? Örneklerle açıklar mısınız?

6. Size göre akademik yöneticilerin sahip olması gereken "Bilişim Liderliği”" kavramının alt boyutları neler olabilir? Liderlerin bu boyutlarla ilgili uygulamaları nasıl olmalıdır? Örneklerle kısaca açıklar mısınız?

7. Bilişim liderliğinin "bilgi ve iletişim” olmak üzere 2 ayrı boyutu olduğu öngörüldüğünde, bilişim liderliğinin "bilgi" boyutuna yönelik ne gibi uygulamaları olabilir? Bu uygulamaları örnek vererek açıklar mısınız?

8. Bilişim liderliğinin "bilgi ve iletişim” olmak üzere 2 ayrı boyutu olduğu öngörüldüğünde, bilişim liderliğinin “iletişim” boyutuna yönelik ne gibi uygulamaları olabilir? Bu uygulamaları örnek vererek açıklar mısınız? 


\section{Ek B: Bilişim Liderliği Ölçeği}

Kurumdaki Yöneticim;

\begin{tabular}{|c|c|c|c|c|c|}
\hline \multicolumn{6}{|c|}{ (Her satırda sadece bir seçeneği işaretleyiniz.) } \\
\hline & $\begin{array}{l}\text { Kesinlikle } \\
\text { Katılmıyorum }\end{array}$ & Katılmıyorum & \begin{tabular}{|l|} 
Kismen \\
Katillyorum \\
\end{tabular} & Katıllyorum & \begin{tabular}{|l|} 
Tamamen \\
Kat1lyorum
\end{tabular} \\
\hline $\begin{array}{l}\text { 1. Bilişim teknolojilerinin riskleri konusunda kurum } \\
\text { çalş̧anlarını bilinçlendirir. }\end{array}$ & $\square$ & $\square$ & $\square$ & $\square$ & $\square$ \\
\hline $\begin{array}{l}\text { 2. Sosyal aktörlerle (STK'ler, belediyeler, meslek } \\
\text { odaları, dernekler vb.) gerçekleştirilen iletişimlerde } \\
\text { bilişim teknolojilerinden yararlanır. }\end{array}$ & $\square$ & $\square$ & $\square$ & $\square$ & $\square$ \\
\hline $\begin{array}{l}\text { 3. Bilgiye erişimde farklı araçları (bilgisayar, } \\
\text { internet, mobil ortamlar vb.) kullanır. }\end{array}$ & $\square$ & $\square$ & $\square$ & $\square$ & $\square$ \\
\hline $\begin{array}{l}\text { 4. Örgütsel süreçleri iyileştirmeye yönelik } \\
\text { kullanılabilecek teknolojilere ilişkin çevresindekileri } \\
\text { bilinçlendirir. }\end{array}$ & $\square$ & $\square$ & $\square$ & $\square$ & $\square$ \\
\hline $\begin{array}{l}\text { 5. Sanal ortamda (sosyal medya, web sitesi vb.) } \\
\text { çalıştığı kurumunu tanıtır. }\end{array}$ & $\square$ & $\square$ & $\square$ & $\square$ & $\square$ \\
\hline $\begin{array}{l}\text { 6. Kurumunda herkesin yararlanabileceği teknolojik } \\
\text { araçlar, kütüphane olanakları gibi bilgi altyapılarını } \\
\text { oluşturma çabası içerisindedir. }\end{array}$ & $\square$ & $\square$ & $\square$ & $\square$ & $\square$ \\
\hline $\begin{array}{l}\text { 7. Bilişim uygulamaları için gerekli etik davranışları } \\
\text { tüm paydaşlarıyla birlikte belirler. }\end{array}$ & $\square$ & $\square$ & $\square$ & $\square$ & $\square$ \\
\hline $\begin{array}{l}\text { 8. Düzenlenen toplantılarda bilişim } \\
\text { teknolojilerinden yararlanır. }\end{array}$ & $\square$ & $\square$ & $\square$ & $\square$ & $\square$ \\
\hline $\begin{array}{l}\text { 9. Yönetimde bilgi teknolojilerini faal bir şekilde } \\
\text { kullanır. }\end{array}$ & $\square$ & $\square$ & $\square$ & $\square$ & $\square$ \\
\hline $\begin{array}{l}\text { 10. Bilişim teknolojilerinin getirdiği yeniliklere karş1 } \\
\text { direnci azaltmak için bilgilendirici bir rol üstlenir. }\end{array}$ & $\square$ & $\square$ & $\square$ & $\square$ & $\square$ \\
\hline $\begin{array}{l}\text { 11. Farklı disiplinlerden meslektaşları ile ilişkiler } \\
\text { geliştirmede bilişim teknolojilerinden yararlanır. }\end{array}$ & $\square$ & $\square$ & $\square$ & $\square$ & $\square$ \\
\hline $\begin{array}{l}\text { 12. Bilişim teknolojilerine ilişkin araştırma - } \\
\text { geliştirme faaliyetlerine önem verir. }\end{array}$ & $\square$ & $\square$ & $\square$ & $\square$ & $\square$ \\
\hline $\begin{array}{l}\text { 13. Çalışma arkadaşlarının öğrenen örgüt } \\
\text { yapısına katkılarını arttıracak teknolojik olanaklar } \\
\text { konusunda kendi tecrübelerini paylaşır. }\end{array}$ & $\square$ & $\square$ & $\square$ & $\square$ & $\square$ \\
\hline $\begin{array}{l}\text { 14. Uluslararass ilişkiler geliştirmek için bilişim } \\
\text { teknolojilerinden yararlanır. }\end{array}$ & $\square$ & $\square$ & $\square$ & $\square$ & $\square$ \\
\hline $\begin{array}{l}\text { 15. Bilişim alanındaki gelişmeleri yakından takip } \\
\text { eder. }\end{array}$ & $\square$ & $\square$ & $\square$ & $\square$ & $\square$ \\
\hline $\begin{array}{l}\text { 16. Kurumsal vizyona katılımı artırmak için kurum } \\
\text { çalışanlarının yararlanabilecekleri teknolojik araçlar } \\
\text { konusunda yönlendirme yapar. }\end{array}$ & $\square$ & $\square$ & $\square$ & $\square$ & $\square$ \\
\hline $\begin{array}{l}\text { 17. Kurumsal iletişim ağlarının kurulmasında } \\
\text { bilişim teknolojilerinden yararlanılmasına öncülük } \\
\text { eder. }\end{array}$ & $\square$ & $\square$ & $\square$ & $\square$ & $\square$ \\
\hline $\begin{array}{l}\text { 18. Bilgi edinme sürecinde bilişimle ilgili eğitim } \\
\text { faaliyetleri düzenler. }\end{array}$ & $\square$ & $\square$ & $\square$ & $\square$ & $\square$ \\
\hline
\end{tabular}


